\title{
Norway Spruce Provenance Experiments in the Maritimes Region of Canada
}

\author{
by \\ D. P. Fowler ${ }^{1}$ and J. F. Coles ${ }^{1}$
}

\begin{abstract}
Results from ten provenance trials of Norway spruce in the Maritimes Region are reviewed. Norway spruce from eastern Poland and from mid-elevations in the Sudeten and Carpathian Mountains of northern Poland can be expected to perform well when planted over a wide range of sites in central and southern New Brunswick, Prince Edward Island and Nova Scotia. Norway spruce from east of the Baltic Sea, i.e., northeastern Poland, Latvia, Lithuania, western Russia and White Russia is recommended for northern New Brunswick. These same provenances are recommended for use in Great Lakes - St. Lawrence Region of Quebec and Ontario.

Survival and growth rate of Norway spruce are compared to that of native spruce species. In general, survival of black and Norway spruce was the same and exceeded that of white and red spruce. Black spruce was taller than Norway which was taller than white and red spruce in most tests. It is suggested that growth of Norway spruce will exceed that of native spruces over rotations of 40-50 years.
\end{abstract}

\section{Résumé}

Revue des résultats de dix essais de provenances d'Epinette de Norvège dans la Région des Maritimes. On peut s'attendre à une bonne performance de l'Epinette de Norvège provenant de l'est de la Pologne et des moyennes altitudes des Sudètes et des Carpates dans le nord de la Pologne, dans une vaste gamme de stations du centre et du sud du Nouveau-Brunswick, de l'lle-du-Prince-Edouard et de la Nouvelle-Ecosse. L'Epinette de Norvège provenant de l'est de la mer Baltique, soit le nord-est de la Pologne, la Latvie, la Lithuanie, la Russie de l'ouest et la Russie blanche, est recommandée pour le Nouveau-Brunswick. Ces mêmes provenances sont recommandées pour la Région des Grands lacs et du StLaurent au Québec et en Ontario.

La survie et le taux de croissance de l'Epinette de Norvège sont comparés à ceux des espèces indigènes d'Epinette. De façon générale, la survie de l'Epinette noire et de l'Epinette de Norvège a été identique et supérieure à celle de l'Epinette blanche et de l'Epinette rouge. L'Epinette noire était plus haute que l'Epinette de Norvège, laquelle était plus haute que l'Epinette blanche et l'Epinette rouge dans la plupart des essais. II est à prévoir que la croissance de l'Epinette de Norvège dépassera celles des espèces indigènes d'Epinette au cours de révolutions de 40 à 50 ans.

\section{Introduction}

Norway spruce, Picea abies (L.) Karst., was the most widely planted non-native conifer in eastern North America during the late 1800's and early 1900's. In North America the species attains its best growth on moist, cool, acid sites in the temperate climate of northeastern United States and eastern Canada (Holst and Heimburger 1969) where it has been reported to be superior to native species growing on comparable sites (Hosley 1936, Hawley and Lutz 1943, Hughes and Loucks 1962, MacArthur 1964). The species is slower growing and generally less suited to the drier, more continental, and boreal climate of central Canada (Holst 1963, Klein 1977). It has never been extensively planted in western Canada where appropriate sites are occupied by more rapid-growing native species.

${ }^{1}$ Maritimes Forest Research Centre, Canadian Forestry Service, Fredericton, New Brunswick
Despite the importance of Norway spruce in early reforestation efforts in the northeast, it has not maintained the same popularity in current planting programs. Today less than 10 million seedlings of Norway spruce are planted annually in eastern Canada (Morgenstern and Carlson 1979). Norway spruce has failed to find wide acceptance as a reforestation species, primarily because of biotic factors not encountered within its natural range. The species is highly susceptible to the white pine weevil, Pissodes strobi (Peck), and in areas of high weevil incidence a large proportion of planted trees can be seriously damaged. It is also susceptible to damage by the spruce budworm, Choristoneura fumiferana (Clemens) and the porcupine, Erethizon dorsatum dorsatum L.; in addition, the pine grosbeak, Pinicola enucleator L., and the red squirrel, Tamiasciurus hudsonicus (Erxleben) feed on buds and can, on occasion, cause serious damage.

Cold resistance is generally not a serious problem with Norway spruce planted on good spruce sites in eastern Canada (Fowler and Coles 1979). In more continental situations and especially when planted off-site or in frost pockets, serious damage can occur (Van Deusen and Nienstaedt 1978). On the other hand, winter drying or winter browning is common on Norway spruce planted on moderately exposed sites throughout the Maritimes (Fowler and Coles 1979) and is especially prevalent on trees just emerging above snow cover. Winter drying is generally not serious except in extreme situations, for, although foliage may be lost, the buds survive and grow normally.

The first range-wide trials of Norway spruce in North America were initiated in the late 1930's in cooperation with the International Union of Forest Research Organizations (IUFRO). Holst (1963), in reviewing the results of these IUFRO trials concludes that choice of seed source for use on good spruce sites in northeastern United States and eastern Canada is not critical. He suggests that fastgrowing, moderately-hardy provenances such as Crucea and Valdu Rau (Romania), Stolpce (Russia), Sveriosice (Czechoslovakia), Dolina (Ukrainian SSR) and Istebna (Poland) will produce more wood than native red spruce (Picea rubens Sarg.), black spruce (P. mariana (Mill.) B.S.P.) and white spruce ( $P$. glauca (Moench) Voss.). This generally supports the recommendations of Baldwin (1953) for northeastern United States. Ashman (1958) suggests that seeds from the mountains of central Europe are satisfactory for the State of Maine. Holst (1963) considers proper choice of seed source to be more critical for the continental areas of North America and suggests that Norway spruce be planted only on rich fresh sites within the natural range of white spruce. He recommends the use of Norway spruce from the southeast corner of the Baltic Sea, Poland, and White Russia. Although not recommended for large-scale planting, Polish provenances are considered best for the Lake States (Slabaugh and Rudolf 1957, King and Rudolf 1969, Van Deusen and Nienstaedt 1978) and the northern Great Plains (Van Deusen and Nienstaedt 1978). Further north, in the boreal forest of west-central Manitoba, Russian provenances from the southern coniferous zone between 57 and $65^{\circ}$ E longitude appear most promising (Klein 1977). 


\section{Results of Norway Spruce Tests in the Maritimes Region of Canada}

Starting in the late 1950's the Maritimes Forest Research Centre of the Canadian Forestry Service embarked on a long-term program of provenance testing of Norway spruce. The objectives of this program are to determine the best Norway spruce provenances for use in various parts of the Maritimes Region and to accumulate materials for future selection and breeding. From 1961 to 1972 , ten separate Norway spruce trials were established. One trial, experiment 43 , is a range-wide study and is the only North American planting of the IUFRO 1964/1968 trial. The others are trials of provenances from parts of the species range considered to have promise for the Region. The number of provenances tested in each experiment is listed by country of origin in Table 1. Native spruces were included as controls in all but one test. One replicated plantation of each of the 10 trials was planted on or near the Acadia Forest Experiment Station near Fredericton, New Brunswick. Other replicated experiments were established elsewhere in the

Table 1. Summary of provenance trials established by the Canadian Forestry Service in the Maritimes Region of Canada during 1961-1972

\begin{tabular}{lllllllllll}
\hline $\begin{array}{l}\text { Experi- } \\
\text { ment } \\
\text { No. }\end{array}$ & 16 & 31 & 33 & 35 & 40 & 41 & 42 & 43 & 70 & 99 \\
\hline $\begin{array}{l}\text { Year } \\
\text { planted }\end{array}$ & 1961 & 1967 & 1967 & 1969 & 1971 & 1970 & 1972 & 1967 & 1972 & 1972 \\
\hline $\begin{array}{l}\text { Number of } \\
\begin{array}{l}\text { Test } \\
\text { Locations }\end{array}\end{array}$ & 4 & 1 & 1 & 3 & 2 & 2 & 1 & 1 & 2 & 1 \\
\hline
\end{tabular}

Table 1. Summary of provenance trials established by the Canadian Forestry Service in the Maritimes Region of Canada during 1961.1972

Number of Provenances Tested

\section{NORWAY}

SPRUCE

\section{Origin}

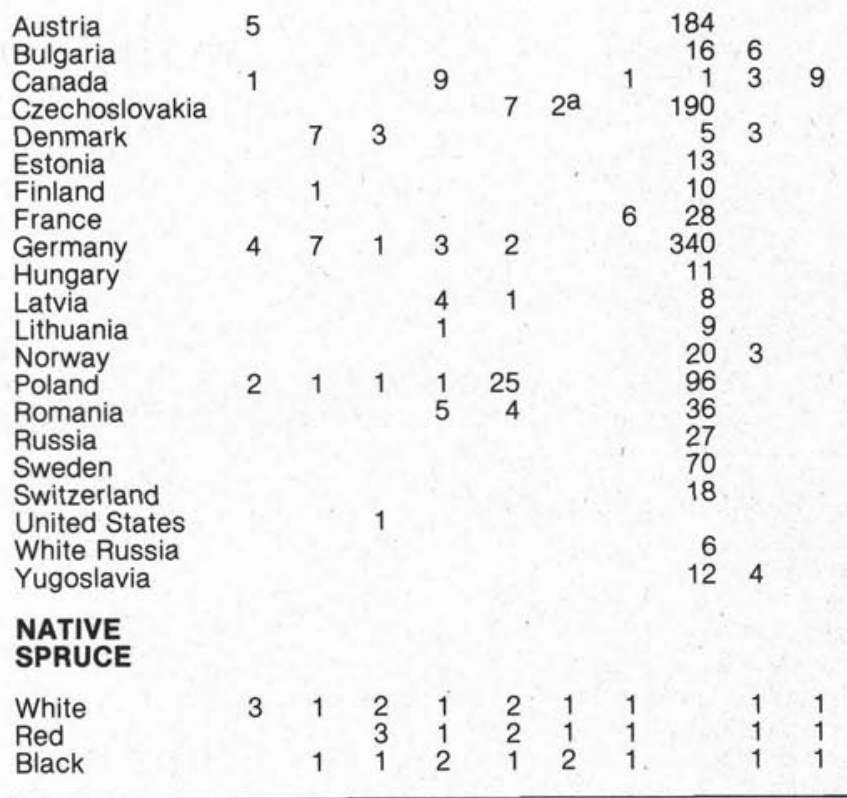

a Each provenance represented by 10 single progenies.

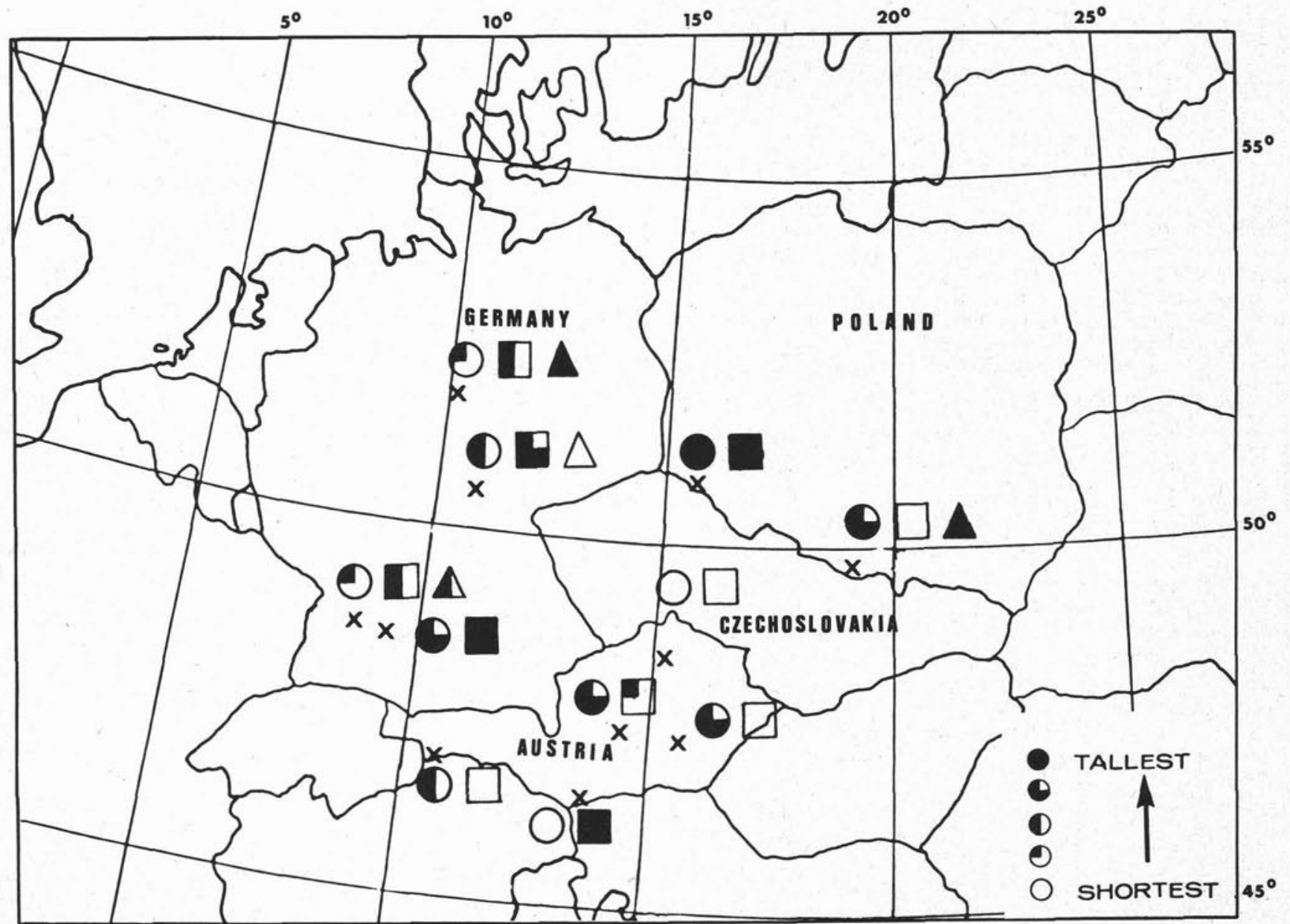

Fig. 1. Experiment 16. Geographic origin and relative height of Norway spruce in experiments $16 \mathrm{~A}$ - Acadia Forest Experiment Station (0); 16 B - Green River, N.B. ( $\square$ ); and 16 (PFES) - Corbett Lake, N.S. ( $\triangle$ ), from Fowler and Coles (1979). 
Maritimes Region. In addition, several unreplicated "observation" plots were established to provide supporting information and additional materials for future selection and breeding.

Results from all 10 experiments are reported in detail by Fowler and Coles (1979) and are summarized as follows:

\section{Sudeten and Carpathian Mountains}

Norway spruce from mid-elevations in the Sudeten and Carpathian Mountains of Poland grows well in all but the most northern parts of New Brunswick. Variation among Czechoslovakian provenances appears quite high, making these provenances less reliable than Polish provenances from roughly the same area. Norway spruce from farther south in the Carpathians of Romania has generally proven to be less satisfactory but should be further tested in the milder parts of the Region, (experiments 16, 35, 40, and 43; Fig. 1, 2,3 , and 4).

\section{Northern Europe}

Norway spruce from north of the Baltic Sea and from northern and central Russia is consistently slow-growing and has only average to below-average survival (experiment 43 , Fig. 4),

\section{East of Baltic Sea}

Norway spruce from eastern Poland is among the most promising for use throughout the Maritimes Region, although materials from Latvia, Lithuania, western Russia, and White Russia perform best in the climatically more rigorous parts of the Region, (experiments 35, 39-40, and 43; Fig. 2, 3, and 4).

\section{East Germany}

The performance of Norway spruce from Germany has proven to be extremely variable under Maritime conditions (experiments 16, 35, 39-40, and 43; Fig. 1, 2, 3, and 4). Some provenances rank well while others from essentially the same locations are among the poorest. If German provenances are to be used, it will be necessary to identify and test at the individual stand or plantation level.

\section{Alps and Jura Mountains}

Norway spruce from the Alps and Jura Mountains (experiments $16,39-40$, and 43 ; Fig. 1,3 , and 4 ) has proven to be highly variable and is generally unsatisfactory for use in the Maritime Region. Specific provenances may however be useful for climatically rigorous parts of the Region.

\section{Dinaric Alps and Balkan Mountains}

Norway spruce from the Dinaric Alps and Balkan Mountains (experiment 43, Fig. 4) is generally not suited for use in the Maritimes Region.

\section{Non-Native Provenances}

Norway spruce has been widely planted outside its natural range in Europe as well as in North America. The true origin of these "provenances" and the extent to which

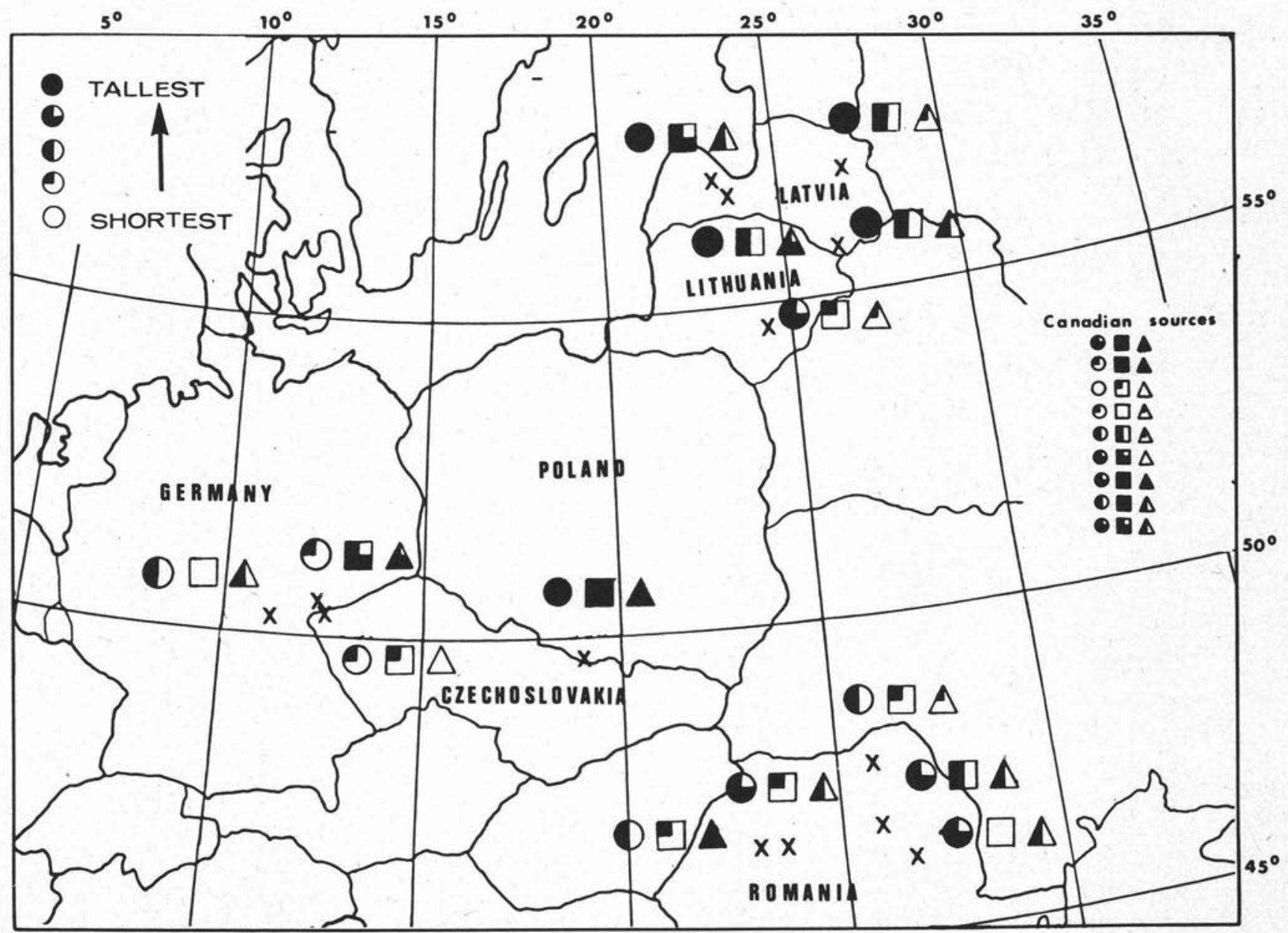

Fig. 2. Experiment 35. Geographic origin and relative height of Norway spruce in $35 \mathrm{~A}-$ Edmundston, N.B. (0); $35 \mathrm{~B}-\mathrm{Acadia}$ Forest Experiment Station ( $\square$ ); and 35C - Caledonia, N.S. ( $\Delta$ ), from Fowler and Coles (1979). 
they have been influenced by local selection (natural and man) are generally not known. Despite this lack of information, non-native provenances, especially those within ones own political jurisdiction, are potentially valuable sources of seed.

As might be expected, the performance of trees of nonnative provenance is highly variable and rather unpredictable (experiments 16, 35, 43; Fig. 1, 2, and 4). For example some populations of Danish and Canadian provenance ranked among the best while others were among the poorest in these experiments. Unfortunately, the local Maritimes provenances were rather poor.

\section{Comparison with Native Species}

Average survival of Norway spruce and black spruce is the same $(86 \%)$ in the 13 tests in which comparisons can be made. Norway spruce generally survives better than either white spruce ( $86 \%$ vs $79 \%$ for 15 tests) or red spruce $(87 \%$ vs $78 \%$ for 12 tests). Black spruce is taller than the best Norway spruce in all but one of 13 tests. The mean annual height increment over 13 tests is $20.4 \mathrm{~cm}$ for black spruce and $16.4 \mathrm{~cm}$ for Norway spruce. Height growth of Norway spruce generally exceeds that of white spruce (mean annual height increment $16.7 \mathrm{~cm}$ vs $14.0 \mathrm{~cm}$ for 15 tests) and red spruce ( $15.8 \mathrm{~cm}$ vs $12.4 \mathrm{~cm}$ for 12 tests).

Norway spruce is more susceptible to damage by white pine weevil than any of the three native spruces, is more heavily damaged by spruce budworm than black spruce, and is more susceptible to winter drying than either black or white spruce.

The exceptionally good, overall performance of black spruce for height growth in these experiments is somewhat surprising and does not support the conclusion that Norway spruce of better provenances will outproduce native spruces in eastern Canada (Holst 1963, MacArthur 1964). It should, however, be emphasized that the trees in these experiments are only 5 to 16 years from planting and that growth assessment is based primarily on height. It has been established that Norway spruce is capable of maintaining good height and volume growth over rotations of 50 years or more, on good sites in eastern North America (Hosley 1936, Hawley and Lutz, 1943, Hughes and Loucks 1962). Similar information is not available for plantation-grown black spruce. Final evaluation of Norway spruce as an alternative to native spruces for reforestation in eastern Canada must be postponed until comparable data on volume growth and wood characteristics are available. Intuitively, however, we believe that managed Norway spruce plantations of good provenance, on good sites, will surpass black spruce in volume growth over rotations of 40 to 50 years or more.

\section{Provenance Recommendations}

At the present stage of provenance testing of Norway spruce in North America, identification of best provenance at the stand or local population level has little practical value. Aside from the fact that most tests fail statistically to identify single best provenances, identification of best provenance is usually impractical for one or more of the following reasons:

1. Seed procurement from individual stands outside Canada is usually difficult to arrange and control.

2. The stands chosen for testing and subsequently identified as best, may not be suitable for commercial seed

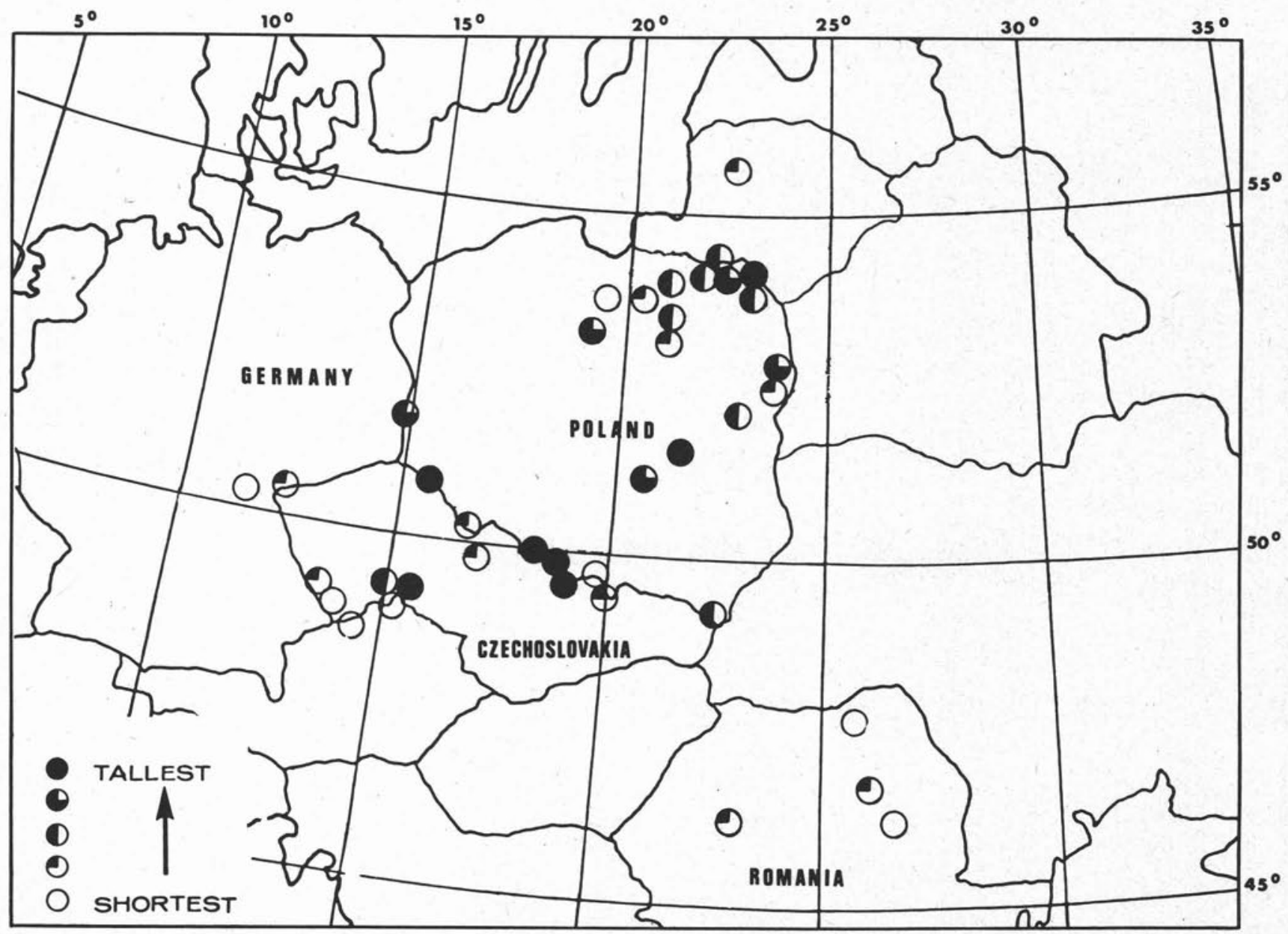

Fig. 3. Experiment 39-40. Geographic origin and relative height of Norway spruce in experiment 39-40A Acadia Forest Experiment Station, from Fowler and Coles (1979). 
collection because of size, ownership, or some other reason.

3. The original stand from which seed was collected may no longer exist.

4. Seeds from a single stand planted over wide areas will be of limited value for future breeding work because of the restricted genetic base.

Primarily for the above reasons, areas of best provenances are recommended and further it is recommended that genetically broad-based seed collections, i.e., collections from several stands, be favored over single stand collections.

Reliable information upon which to base provenance recommendations is available only for eastern Canada. Provenance recommendations for the rest of Canada are more tenuous.

In central and southern New Brunswick, Prince Edward Island, and Nova Scotia, Norway spruce from eastern Poland and from mid-elevations in the Sudeten and Carpathian Mountains of southern Poland can be expected to perform well when planted over a wide range of moist, cool, acid sites. Norway spruce from the Carpathian Mountains of Romania, contrary to Holst's (1963) recommendation, has failed to distinguish itself in eastern Canada.

In northern New Brunswick, Norway spruce from east of the Baltic Sea, i.e., northern Poland, Latvia, Lithuania, western Russia and White Russia appears best. In the eastern part of the Great Lakes - St. Lawrence Forest Region (Rowe 1959) of Quebec and eastern Ontario where non-native provenances from Quebec and Ontario and second generation Swedish provenances from German plantations have done well (Corriveau 1976, 1979), provenances from Poland and from east of the Baltic can also be recommended. More meaningful recommendations will be possible when detailed information is available from the many provenance tests established in this Region over the last decade (Corriveau 1976). Further west in the Great Lakes St. Lawrence Forest Region of Ontario and the adjacent Lake States where choice of appropriate planting sites is more critical (Holst 1963), Norway spruce from these same provenances, east of the Baltic Sea, can be expected to perform well.

Norway spruce does not appear to be a realistic alternative to native spruces as a general reforestation species in central and western Canada. Further testing of Norway spruce from Russia, and from eastern Europe (Klein 1977) is required however before this can be verified.

\section{Acknowledgments}

The authors acknowledge the contribution to this study of H. G. MacGillivray, M.F.R.C. (retired) whose foresight in establishing most of the tests made this evaluation of Norway spruce possible. We also acknowledge the contribution of Mark Holst, PNFI (retired) who provided much of the incentive and most of the seeds for these trials.

\section{References}

Ashman, R. I., 1958: The possibilities of Norway spruce in Maine. Proc. 5th Northeastern Forest Tree Improvement Conf. 43-45.

Baldwin, H. I., 1953: Provenance tests of common exotics in the northeast. Proc. 1st Northeastern Forest Tree Improvement Conf. 33-38.

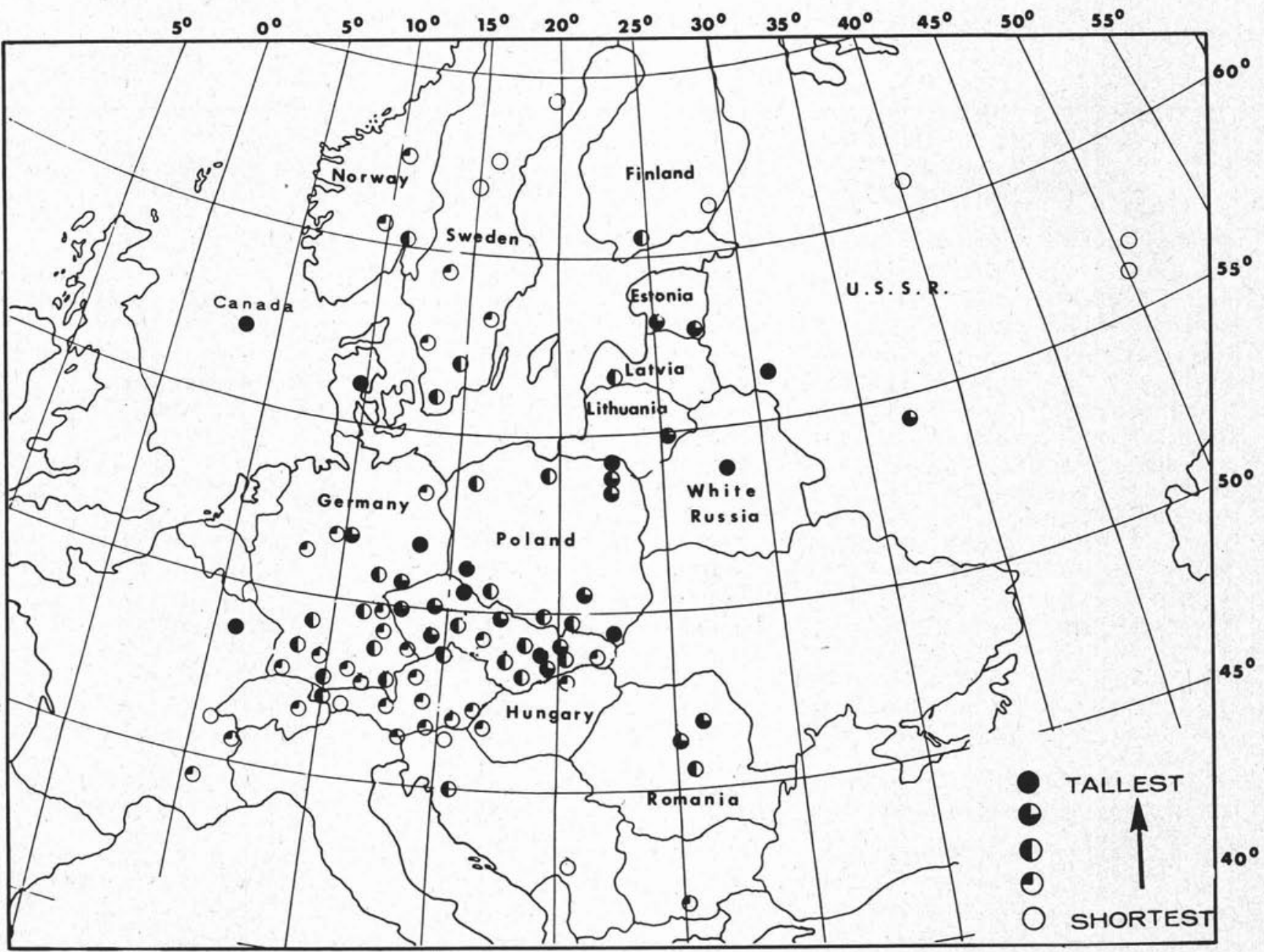

Fig. 4. Experiment 43. Geographic origin and relative height of Norway spruce, grouped by provenance areas, in experiment $43-$ Chipman, N.B., from Fowler and Coles (1979). 
Corriveau, A. G., 1976: L'épinette de Norvège. In. L'amélioration génétique des espèces forestières au Québec. Min. Terres et Forêts. Serv, Rech, Mem. 30: 125-149.

Corriveau, A. G., 1979: Québec. In. Tree seed production and tree improvement in Canada - research and development needs 1977-1987. Appendix A.

Fowler, D. P., and Coles, J. F., 1979: Provenance trials of Norway spruce in the Maritimes. Can. For. Serv. Marit. For. Res. Cent. Inf. Rep. M-X-101.

Hawley, R. C., and Lutz, H. J., 1943: Establishment, development, and management of conifer plantation in the Eli Whitney Forest. New Haven, Conn. Yale Univ. School For. Bull. 53.

Holst, M. J., 1963: Growth of Norway spruce (Picea abies (L.) Karst.) provenances in eastern North America. Can. Dep. For. Publ. 1022.

Holst, M. J., and Heimburger, C. C., 1969: Tree breeding and genetics of exotic conifers in Canada. For. Chron. 45: 434-440.

Hosley, N. W., 1936: Norway spruce in the northeastern United States. Harvard For. Bull. 19.

Hughes, E. L., and Loucks, O. L., 1962: Rapid growth of Norway spruce and some native spruces in New Brunswick. Pulp, Paper Mag. Canada, Woodlands Review 63: 3-6.
King, J. P., and Rudolf, P. O., 1969: Development of white and Norway spruce trees from several seed sources 29 years after planting. U.S. For. Serv, Res. Note NC - 70.

Klein, J. I., 1977: Survival and growth of Norway spruce populations in Manitoba 14 years after planting. Can. For. Ser. Nor. For. Res. Cent. Inf. Rep. NOR-X-179.

MacArthur, J. D., 1964: Norway spruce plantations in Quebec, Can. Dep. For. Publ. 1059.

Morgenstern, E. K., and L. W. Carlson, 1979. (Eds.) Tree seed production and tree improvement in Canada - research and development needs 1977-1987. Environ. Can. For. Serv. Inf. Rep. PS-X-74. 99p plus 10 appendices.

Rowe, J. S., 1959: Forest Regions of Canada. Can. Dep. North. Affairs, Nat. Res. For. Br. Bull. 123.

Slabaugh, P. E., and Rudolf, P. O., 1957: The influence of seed source on the development of Scotch pine and Norway spruce planted in Lower Michigan (15-year results). Mich. Acad. Sci. Arts, Letters. Pap. (1956) 42: 41-52.

Van Deusen, J. L., and Nienstaedt, H., 1978: A trial of eleven sources of Picea abies in North Dakota and Minnesota. Proc. N. D. Acad. Sci. 31: 32-39.

\title{
CIF/IFC 1980 OTTAWA ....

\section{CO-ORDINATOR - FOREST MANAGEMENT GROUP}

Required by the Woodlands Section, Canadian Pulp and Paper Association, Montreal, Quebec.

The applicant for this position will be a person with professional forestry qualifications who is familiar with Canadian industrial forestry practices. He will have had progressively responsible experience on forest management operations demonstrating administrative, organizational and supervisory ability. This career position involves some travel and offers an excellent opportunity and professional challenge to a person who has the ability to communicate effectively with professional people from a wide range of disciplines within the forest industry, research organizations and government agencies. The successful candidate will report to the Manager. Woodlands Section and will be responsible for coordinating the activities and work program of the Forest Management Group. This Group consists of about 60 representatives of Member Companies of the Canadian Pulp and Paper Association and some 20 liaison members from governments, research organizations and forestry schools across Canada. They collect and distribute information on industrial forestry, assist individuals and companies with forestry affairs, and make representations to Governments concerning the use of forests and forest policies.

A working knowledge of both French and English will be a definite asset, as well as an understanding of current forest management policies, environmental and recreational concepts and practices, and the management of human resources.

The vacancy is available immediately, salary will be negotiated according to experience and qualifications and excellent fringe benefits are available. All applications will be treated with strict confidence.

Please submit letters of application and resumés marked "PERSONAL" to:

\author{
D. C. MacGregor \\ Manager, Woodlands Section \\ Canadian Pulp and Paper Association \\ 2300 Sun Life Building \\ Montreal, P.Q. H3B 2X9
}

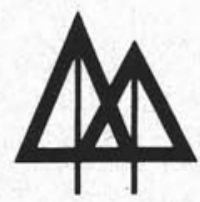

